\title{
The Determinants of Life Insurance Demand In Central and Southeastern Europe
}

\author{
Jordan Kjosevski \\ Corporate sector lending, Stopanska Banka AD, Skopje \\ PO box 6000, Ohrid, Pitu Guli No 5, Republic of Macedonia \\ Tel: 389-070/247-772 E-mail: jordan_kos@yahoo.com
}

Received: December 11, 2011

Accepted: January 5, $2012 \quad$ Published: March 1, 2012

doi:10.5539/ijef.v4n3p237

URL: http://dx.doi.org/10.5539/ijef.v4n3p237

\begin{abstract}
The main purpose of this study is to identify determinants of the demand of life insurance in 14 countries in Central and South- Eastern Europe (CSEE). We use fixed-effects panel model for the period 1998 - 2010 allowing each cross-sectional unit to have a different intercept term serving as an unobserved random variable that is potentially correlated with the observed regressors. We use two measures as a demand for life insurance: life insurance penetration and life insurance density. The research results show that higher, GDP per capita, inflation, health expenditure, level of education and rule of law are the most robust predictors of the use of life insurance. Real interest rates, ratio of quasi-money, young dependency ratio, old dependency ratio control of corruption and government effectiveness do not appear to be robustly associated with life insurance demand.
\end{abstract}

Keywords: Life insurance, Life insurance demand, Central and South- Eastern Europe countries

\section{Introduction}

Life insurance demand has experienced a rapid growth over the last few decades, both as provider of financial services to consumers and as a major investor in the capital market. But, the growth of life insurance did not raise on the same level, not only among industrial countries and developing countries, but also there is a difference between developing countries. The large disparity across countries in the use of life insurance raises questions about what causes this variation and thus what determines life insurance consumption. A number of authors have proposed a variety of different socio-economic and institutional factors as possible determinants of life insurance consumption.

This paper contribution resides in a new effort to understand what drives the life insurance consumption within a sample of 14 Central and South- Eastern Europe (Albania, Bulgaria, Croatia, Czech Republic, Estonia, Hungary, Latvia, Lithuania, Macedonia, Poland, Romania, Slovak Republic, Slovenia and Ukraine) for the period 1998 - 2010. As a measurers of life insurance demand we use: life insurance penetration (life insurance premiums in relation to GDP) and life insurance density (life insurance premiums per capita in constant dollars). We apply linear country specific fixed effects panel data regression model with common coefficients across all cross-section members of the pool. We have chosen fixed effects in each of two models for capturing the effects of unobserved variables that are potentially correlated with observed regressors.

The paper is organized as follows. Section 2 highlights literature on theoretical and empirical findings relevant to the demand for life insurance. Section 3 presents methodology and data, which we incorporate in the analysis. The results of the empirical research are given in section 4. The paper finishes with some concluding remarks and suggestions for the future work that are outlined in section 5 .

\section{Literature Review}

In this section first we present the theoretical research and highlight the most relevant findings in the field of life insurance demand. The theoretical frameworks usually are followed by the empirical investigation of the developed models, so in the first part of literature review we will highlight both the models and the empirical findings, where they are present. Then we proceed to the empirical studies which for the most part evaluate factors' impact on life insurance demand in particular countries and across them.

\subsection{Theoretical Studies}

Yaari (1965) was the first to develop a theoretical model to explain the demand for life insurance. He developed the 
life-cycle utility model of a consumer together with deducing the optimal consumption and optimal saving plans of a consumer. The consumer maximizes lifetime utility subject to a vector of interest rates and a vector of prices including insurance premium rates. This model posits the demand for life insurance to be a function of wealth, expected income over an individual's lifetime, the level of interest rates, the cost of life insurance policies (administrative costs), and the assumed subjective discount rate for current over future consumption.

Lewis (1989) used the life insurance framework developed by Yaari (1965) in his paper extending it in the sense that he included in his model the preferences of other members of the household. While, earlier studies were based on the assumption that life insurance is purchased to maximize the lifetime utility of the individual purchasing the life insurance product, the primary wage earner, Lewis's suggests that life insurance should be purchased to satisfy the needs of survivors. His model does not explicitly rely on the primary wage earner having a bequest motive. However, it does require that the preferences of the beneficiaries be the basis for the amount of life insurance purchased by the household. Deriving utility maximization by both spouse and offspring separately and assuming no bequest by the policyholder and an isoelastic utility function, Lewis shows that total life insurance demand can be written as follows:

$$
(1-\mathrm{lp}) \mathrm{F}=\max \left\{\left[\frac{1-1 l p}{l(1-p)}\right]^{1 / \delta} \mathrm{TC}-\mathrm{W},\right\}
$$

where $l$ is the policy loading factor - the ratio of the costs of the insurance to its actuarial value -, $p$ the probability of the primary wage earner's death, $F$ the face value of all life insurance written on the primary wage earner's life, $\delta$ a measure of the beneficiaries' relative risk aversion, $T C$ the present value of consumption of each offspring until he/she leaves the household and of the spouse over his/her predicted remaining life span ands $W$ the household's net wealth.

Life insurance consumption, however, is not only driven by consumer demand. Price, is undoubtedly an important determinant in the consumption of life insurance. Varying levels of urbanization, monetary stability, bureaucratic quality, rule of law, corruption, and banking sector development all impact the insurer's ability to provide cost-effective insurance. Within the Lewis model, described above, these supply-side factors might be represented by the policyloading factor.

In short, the theoretical review yields variables like income, rate of interest, current consumption and accumulated savings in wealth form as variables influencing insurance consumption. Demographic and social variables were also incorporated in theoretical models and their potential impact on an individual's life insurance consumption decision was investigated. Life insurance consumption increases with the breadwinner's probability of death, the present level of family's consumption and the degree of risk aversion. However, there is no concrete evidence as to how many such non-economic or additional economic variables can play a role in theoretical models. In the next section, we explore selected empirical studies to highlight those variables which were significant in affecting insurance demand.

\subsection{Review of the Empirical Literature}

In this section we present a brief sublimate of empirical literature concerning the relationship between insurance sector and economic growth. When it is noted that often the relationship between insurance sector and economic growth is explored in panel context (studies of groups of countries).

Fortune (1973) was first to focus on the sensitivity relationship between life insurance purchase and financial variables, and linked his implications with the monetary policy and capital markets. He analysed the US insurance market for 1964-1971 and found a high degree of sensitivity between the optimal amount of life insurance, wealth and the real interest rate.

Beenstock et al. (1988) using an international dataset (12 countries over a period of 12 years) to examine the relationship between property liability insurance premiums and income, found out that marginal propensity to insure i.e., increase in insurance spending when income rises by $1 \$$, differs from country to country and premiums vary directly with real rates of interest. Thus, again the decision of consumer and his/her initial wealth status too are significant factors when shortrun or longrun consumption of insurance is considered.

The study by Truett et al. (1990) discussed the growth pattern of life insurance consumption in Mexico and United States in a comparative framework, during the period 1964 to 1984 . They assumed that at an abstract level demand depends upon the price of insurance, income level of individual, availability of substitute and other individual and environment specific characteristics. Further, they experimented with demographic variables like age of individual insured and size of population within the age group 25 to 64 and also considered education level to have some bearing on insurance consumption decision. Their results show the existence of higher income inelasticity of 
demand for life insurance in Mexico at low income levels. Age, level of education and income were significant factors affecting the demand for life insurance in both the countries.

Starting with a brief review of Lewis's (1989) theoretical study and an assumption that inhabitants of a country are homogeneous relative to those of other countries, the study by Browne et al. (1993) expanded the discussion on life insurance demand by adding newer variables namely, average life expectancy and enrollment ratio of third level education. The study based on 45 countries for two separate time periods (1980 and 1987) concluded that income and social security expenditures are significant determinants of insurance demand, however, inflation has a negative correlation. Dependency ratio, education and life expectancy were not significant but incorporation of religion, a dummy variable, indicates that Muslim countries have negative affinity towards life insurance.

Based on a cross-sectional analysis of 45 developing countries, Outreville (1996) analysed the demand for life insurance for the period 1986. In his study he considered variables such as agricultural status of the country represented by the percentage of agricultural labour force; health status of the country in terms of amenities like percentage of population with access to safe drinking water; percentage of labour force with higher education and the level of financial development as factors explaining insurance demand other than the variables we have discussed above. Two dummy variables were used to reflect the extent of competition in the domestic market and foreign participation in the countries considered. The results show that personal disposable income and level of financial development significantly relates to insurance development.

Beck and Webb (2002) made a research over 68 countries of the world, paying attention to the question what causes the variance in life insurance consumption between different countries. They use four different measures of life insurance consumption and incorporate various economic, demographic and institutional factors in their research. As a result, they find that countries with higher income per capita level, more developed banking sector and lower inflation tend to consume larger amounts of life insurance. In addition, life insurance consumption is observed to be positively influenced by private savings rate and real interest rate. Education, young dependency ratio, life expectancy, and size of social security appear not to have any robust influence on the life insurance consumption.

In contrast to Beck and Webb (2002) results, the study by Ward et al (2002) is indicative of the fact that improved civil rights and political stability leads to an increase in the consumption of life insurance in the Asian region as well in the OECD region. The results of the study are consistent with the S-curve relationship proposed by Enz (2000), because in the countries with initially high income level the insurance consumption is less sensitive to income increase.

Although there are strong empirical explanations for determinants of life insurance, none of them focus on the Central and South- Eastern Europe countries particular. Only Beck and Webb (2002) include some of former socialist countries of CSEE (Bulgaria, Czech Republic, Hungary, Poland and Slovenia). In order to contribute to filling of the gap, the following is new empirical study on selected countries from the Central and Southeastern Europe (Albania, Bulgaria, Croatia, Czech Republic, Estonia, Hungary, Latvia, Lithuania, Macedonia, Poland, Romania, Slovak Republic, Slovenia and Ukraine).

\section{Data and Methodology}

For our research we focus on factors that determine demand of life insurance in 14 countries in Central and SouthEastern Europe (Albania, Bulgaria, Croatia, Czech Republic, Estonia, Hungary, Latvia, Lithuania, Macedonia, Poland, Romania, Slovak Republic, Slovenia and Ukraine)over the period of 1998 - 2010. In order to get more observations we used annual panel data. Following similar approach used by Beck and and Webb (2003), we use two measures as a demand for life insurance: life insurance penetration and life insurance density. Factors that we use as control variables, which may explain the demand of life insurance, include the following:

- Economic: GDP per capita, level of financial development, inflation, real interest rate;

- Demographic: dependency ratio, level of education;

- Social Factors: health expenditure to GDP;

- Institutional: rule of law, control of corruption and government effectiveness.

Insert Table 1 Here

Data are obtained from various sources. Life insurance penetration and life insurance density are obtained from Sigma, Swiss Re Economic Research \& Consulting, Swiss Re, Zurich and national insurance associations. Education is obtained from EdStats, World Bank. GDP per capita, level of financial development, inflation, real interest rate, dependency ratio and health expenditure to GDP are obtained from World development indicators (WDI) database. Rule of law, control of corruption and government effectiveness is obtained from Worldwide 
Governance Indicators. Table 1 presents the descriptive statistics for all the variables used in the regressions.

Life insurance penetration measures the importance of insurance activity relative to the size of the economy. Life insurance penetration, is not a perfect measure of consumption since it is the product of quantity and price. A higher premium volume might therefore reflect a higher quantity, a higher price or a difference in the mix of mortality and savings element purchased. Lack of competition and costly regulation might increase the price of insurance without implying a higher level of insurance consumption.

The second indicator of life insurance consumption is life insurance density. It indicates how much each inhabitant of the country spends on average on insurance in real international dollars. Consumers that purchase life insurance policies to insure their dependents against mortality risk will potentially buy more coverage and thus a higher face value in richer countries, since the death benefit has to replace a larger income. Therefore we expect life insurance density to be more income elastic than life insurance penetration.

\subsection{Economic Factors}

The significant positive impact of level of income in the economy - GDP was found by all the researchers in the field (e.g Fortune (1973), Campbell (1980), Beenstock, Dickinson, Khajuria (1986), Lewis (1989), Outreville (1996), Beck and Webb (2002), Ward and Zurbruegg (2000) The larger is level of income, the more of life insurance consumer can afford to purchase for several reasons Beck and Webb (2002). First, an individual's consumption and human capital typically increase along with income. This can create a greater demand for insurance (mortality coverage) to safeguard the income potential of the insured and the expected consumption of his/her dependents. Second, life insurance may be a superior good, inasmuch as increasing income may explain an increasing ability to direct a higher share of income towards retirement and investment-related life insurance products. Finally, the overhead costs associated with administrating and marketing insurance make larger size policies less expensive per dollar of insurance in force, which lowers the price of life insurance policies. To measure the income level of countries, we employ real GDP per capita, and we expect to have a positive relationship with life insurance consumption.

Real interest rates are taken in order to reflect the real return of invested money of insurance company. A higher real interest rate increases life insurers' investment returns and thus their profitability, in turn offering greater profitability of financial relative to real investment for potential purchasers of life insurance policies. This is particularly accurate for life savings instruments. Moreover higher real interest rates increase the supply of capital and therefore the ability of life insurance companies to answer to potential demand. On the other, higher interest rates may induce consumers to reduce their life insurance purchases given the anticipation of higher returns. Indeed, the rise in interest rates might reduce the purchase of life insurance as higher returns on alternative assets may switch consumers from savings in life insurance to another type of money accumulation (Lenten and Rulli, 2006).

Real interest rates have not been systematically included in all studies. For example, Browne and Kim (1993) neglect the influence of this variable on life insurance demand. Outreville (1996) finds the correlation of real interest rates with life insurance demand to be almost insignificant. Beck and Webb (2002) appear to detect a positive relationship using average lending rates. However, it can be noted that lending rates contain a credit risk premium that varies from one country to another, depending on its credit default experience. Therefore we expect real interest rates to be ambiguous related to life insurance demand.

Financial development is associated with the widespread securitization of cash flows, which enables households to secure future income through the ownership of financial assets. By offering similar benefits, life insurance is expected to generate higher sales in countries with a high level of financial development. The measurement of financial development is very controversial (Jung, 1986), but two alternative proxies are usually employed. One is the ratio of quasi-money (M2-M1) to the broad definition of money (M2). - shows the complexity of the financial structure (higher ratio indicates higher level of financial development), another is the ratio of M2 to the nominal GDP - financial deepening (demand for money per unit of output). Broad money M2 is often taken as an adequate measure of the financial sector in developing countries in view of the predominance of the banking sector, as well as owing to the lack of data on other financial assets (Hemming and Manson, 1988, and Liu and Woo, 1994). Following mentioned previous studies we use the ratio of quasi-money (M2-M1) as a measure of financial development.We hypothesise positive correlation with life insurance demand.

The next variable used in our research is the inflation rate. It is used to account for monetary discipline. It is expressed by the GDP deflator (annual percentage). As life insurance savings products typically provide monetary benefits over the long term a rise in inflation discourages people's incentives to save, leading to monetary uncertainty, thus making negative impact on the demand for life insurance. The negative impact of inflation had been widely documented in previous researchers (Outreville (1996), Beck and Webb (2002), Ward and Zurbruegg 
(2002), Li et al. (2007)). With this variable, we expect a negative correlation with life insurance demand.

\subsection{Demographic Factors}

Dependency ratio together with education level of a society are key deterministic demographic variables considered in the previous researches. Dependency ratio shows the structure of the household in terms of a number of people, dependent on the main source of income. Campbell (1980) and Burnett and Palmer (1984) argue that the protection of dependents against financial hardships is the major force driving life insurance consumption. As shown in Lewis (1989), the demand for life insurance increases with the expected value of the dependents' lifetime consumption. This expected value obviously increases with the number of dependents. Hence, the greater need to safeguard them against the premature death of the wage earner.

To capture this relationship on aggregate data, most studies use the dependency ratio defined as the ratio of dependents--under 15 and over 64--to the working-age population aged between 15 and 64. Some studies use the median age of the population and the percent of the population between 25 and 64 years of age to depict the age distribution Truett et al. (1990), while others used ratio of young dependents to working population and ratio of old dependents to working population. For the purposes of this paper as a measure of dependency ratio we will use the following ratios: young dependency ratio, and old dependency ratio. With this two variables we expect to be ambiguously correlation with life insurance demand.

The level of education positively affects the demand for life insurance for several reasons. Truett and Truett (1990) argue that a higher level of education is associated with a stronger desire to protect dependents and safeguard their standard of living. Browne and Kim (1993) explain that a higher level of education is a good proxy to measure the risk aversion. An individual's education level is positively related to greater risk aversion. Outreville (1996) also supports the view expressed by Browne and Kim (1993). Additionally, Li et al. (2007) point out that larger duration of education, measured in average years of schooling, leads to a longer pressure of offsprings' dependency, which contributes to a higher demand for life insurance products to protect the dependents. On the other hand, the more people are involved in education process, the less labor force is presented on the market, therefore reducing overall GDP of the country. Therefore, education is hypothesized to be ambiguous related to life insurance demand. As an indicator of the level of education across countries we use tertiary gross enrollment ratio defined by the UNESCO Institute of Statistics as the total enrolment in tertiary education, regardless of age, expressed as a proportion of the eligible school-age population. measure a country's level of education by its.

\subsection{Social Factors}

Social security programs may affect the demand for life insurance in several different ways. First, social security programs proxy national wealth. Furthermore, given that social security benefits come from taxes, which reduce available income to purchase life insurance, high social security expenditure is hypothesized to reduce the consumption of life insurance. Beenstock, Dickinson, and Khajuria (1986), Browne and Kim (1993), Skipper and Klein (2000), Ward and Zurbruegg (2002) and Beck and Webb (2002) showed that the need for life insurance purchase is reduced when government spending on social security is increased.

However, to the extent that social security pension benefits cease upon the wage earner's death and are not replaced by survivorship benefits, the social security benefits represent a household asset that increases family consumption as long as the wage earner survives. As such, social security expenditures may be positively correlated with life insurance consumption. We use the ratio health expenditure to GDP as a proxy for social security expenditures, and we expect country's social security system to be ambiguous correlated with the demand for life insurance products.

\subsection{Institutional Factors}

Political and legal stability is important for a vibrant and growing life insurance market. As life insurance is considered to be a long-term relationships between a consumer and a company, the more stable is the legal system and, therefore, a political system in the country the higher is the willingness of contracting parties to initiate the business relationships.

Levine $(1997,1998)$ showed that a good investor protection will induce a higher economic growth. This situation is particularly applicable to life insurance products where relationship with companies tends to be long term. Moreover, with the increasing complexity of life insurance products, policyholder can suffer from informational asymmetry. The absence of sound legal system may also hamper the efficiency of insurers' investment, decreasing the profitability and increasing the insurance price. Finally, the lack of political stability shortens the economic horizon of both potential buyers and suppliers of life insurance products, dampening the development of a healthy life insurance market. To measure these institutional and political factors, we use two different indicators.

To measure property right protection, we use rule of law index, provided by the The Worldwide Governance 
Indicators. This index reflects perceptions of the extent to which agents have confidence in and abide by the rules of society, and in particular the quality of contract enforcement, property rights, the police, and the courts, as well as the likelihood of crime and violence. Therefore, it is hypothesized a positive relationship with life insurance consumption.

To measure property right protection, we use control of corruption index also provided by the The Worldwide Governance Indicators. This index Reflects perceptions of the extent to which public power is exercised for private gain, including both petty and grand forms of corruption, as well as "capture" of the state by elites and private interests.

As a measure of political stability, we use indicator compiled by the The Worldwide Governance Indicators. This indicator is constructed using a large number of enterprise, citizen and expert survey respondents in industrial and developing countries, as reported by a number of survey institutes, think tanks, non-governmental organizations, and international organizations. He reflects perceptions of the quality of public services, the quality of the civil service and the degree of its independence from political pressures, the quality of policy formulation and implementation, and the credibility of the government's commitment to such policies.

All three institutional factors are measured in units ranging from about -2.5 to 2.5 , with higher values corresponding to better governance outcomes.

Given the cross-sectional and time-series data, we use country specific fixed effects panel data regression model with common coefficients across all cross-section members of the pool. The general equation to be estimated using pooled least squares is:

$$
y i t=\alpha i+x i t \beta+u i t,
$$

where $y i t$ is a dependent variable, xit is a vector of independent variables, uit is a scalar disturbance term, $i$ indexes country in a cross section, and $t$ indexes time measured in years. Since the error terms uit are potentially serially correlated and heteroskedastic, we propose an autoregressive process of first order: uit $=$ puit-1 + eit , where eit is white noise. Model incorporates White's consistent covariance matrix (White, 1980), for dealing with heteroskedasticity.

Given the hypotheses specified above, we construct two separate panel data regression models. The models are different since life insurance demand is represented by two different dependent variables: Insurance penetration and insurance density.

The specifications of the models to be estimated are as under:

Model 1

(life insurance penetration)it $=\alpha \mathrm{i}+\beta 1($ GDP per capita)it $+\beta 2$ (real interest rates)it $+\beta 3$ (QuasiMon/M2)it + $\beta 4$ (Inflation)it $+\beta 5$ (young dependency ratio)it $+\beta 6$ (old dependency ratio)it $+\beta 7$ (education level)it $+\beta 8$ (Health expenditure to GDP)it $+\beta 9$ (rule of law)it $+\beta 10$ (Control of Corruption)it $+\beta 11$ (Government Effectiveness)it + uit

\section{Model 2}

(life insurance density)it $=\alpha i+\beta 1($ GDP per capita)it $+\beta 2$ (real interest rates)it $+\beta 3$ (QuasiMon/M2)it + $\beta 4$ (Inflation)it $+\beta 5$ (young dependency ratio)it $+\beta 6$ (old dependency ratio)it $+\beta 7$ (education level)it $+\beta 8$ (Health expenditure to GDP)it $+\beta 9$ (rule of law)it $+\beta 10$ (Control of Corruption)it $+\beta 11$ (Government Effectiveness)it + uit

Before running the regression an Im, Pesaran and Shin, panel unit-root test, which is based on the Dickey-Fuller procedure was employed to test the stationarity of the variables in order to avoid the spurious regression. Im, Pesaran and Shin denoted IPS proposed a test for the presence of unit roots in panels that combines information from the time series dimension with that from the cross section dimension, such that fewer time observations are required for the test to have power. Since the IPS test has been found to have superior test power by researchers in economics to analyze long-run relationships in panel data, we will also employ this procedure in this study. IPS begins by specifying a separate ADF regression for each cross-section with individual effects and no time trend:

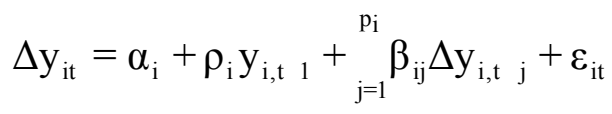

where $i=1, \ldots, N$ and $t=1, \ldots, T$

IPS use separate unit root tests for the $N$ cross-section units. Their test is based on the Augmented Dickey-fuller 
(ADF) statistics averaged across groups. After estimating the separate ADF regressions, the average of the $t$-statistics for $\mathrm{p}_{1}$ from the individual ADF regressions, $\mathrm{t}_{\mathrm{iT}_{\mathrm{i}}}\left(\mathrm{p}_{\mathrm{i}}\right)$ :

$$
\overline{\mathrm{t}}_{\mathrm{NT}}=\frac{1}{\mathrm{~N}} \sum_{\mathrm{i}=1}^{\mathrm{N}} \mathrm{t}_{\mathrm{iT}}\left(\mathrm{p}_{\mathrm{i}} \beta_{\mathrm{i}}\right)
$$

The $t$-bar is then standardized and it is shown that the standardized $t$-bar statistic converges to the standard normal distribution as $\mathrm{N}$ and $\mathrm{T} \rightarrow \infty$. Im, Pesaran and Shin (1997) showed that $t$-bar test has better performance when $\mathrm{N}$ and $\mathrm{T}$ are small. They proposed a cross-sectionally demeaned version of both test to be used in the case where the errors in different regressions contain a common time-specific component.

The results of the unit root test are presented in Table 2. While the null hypothesis of the unit-root was rejected for eight of the thirteen variables, and they are are stationary at their levels I (0); the obtained results indicate that there was a unit root in GDP per capita, young dependency ratio, old dependency ratio, life insurance penetration and life insurance density. To solve the problem of non-stationarity, the series were differenced at first level I(1).

Insert Table 2 Here

\section{Empirical Results}

The models used in this study have been introduced at the end of previous chapter. In this section, we present original results and interpretations concerning both of the observed models.

Insert Table 3 Here

\subsection{Life Insurance Penetration}

The results in Table 4 show that the variation of life insurance penetration across countries significantly and positively depends on income level, average years of schooling and health expenditure to GDP. These three variables show significant coefficients to the 1,5 or 10 per cent level in our baseline regression. Whereas the results for real interest rates, quasimon/M2 inflation, young dependency ratio, old dependency ratio, rule of law, control of corruption and government effectiveness are less robust..

As suggested in the previous studies, GDP per capita has a positive and significant influence on life insurance penetration. The results suggest that a $1 \%$ increase in GDP per capita is associated with an increase of about 0,0168 percentage points.in life insurance penetration. The results are consistent with the models of Campbell (1980) and Lewis (1989). Truett and Truett (1990), Browne and Kim (1993), Outreville (1996), and Beck and Webb (2002) obtain similar coefficients.

The results underline the importance of a high level of education for life insurance consumption. The coefficient on average years of schooling indicating that the rise in average years of schooling by 1 year improves life insurance penetration by 0.0016 percentage points

Reflecting the conflicting indications of previous studies that have sought to determine its effect, health expenditure expenditure appears to have a positive and significant influence on life insurance penetration. Thus $1 \%$ increase in health expenditure expenditure leads to 0.0123 percentage points rise in life insurance penetration. Hence, it would appear as in Browne and Kim (1993) that health expenditure reflects the high level of wealth of a country and should therefore be associated with higher life insurance demand. This result is consistent with Lewis (1989) and confirms the findings of Beenstock, Dickinson, and Khajuria (1986).

Contrary to most previous studies, real interest rates, quasimon/M2, inflation, young dependency ratio, old dependency ratio, rule of law, control of corruption and government effectiveness cannot explain the variation in life insurance density across countries.

As we expected, inflation and real interest rate is inversely related with penetration but are not significant. The relation between inflation and real interest rate with the demand proxies does not corroborate with earlier studies and hence we conclude that current interest rate and real interest rate or price situation does not affect in life insurance penetration.

The value of quasi money to M2 ratio, produces an expected positive sign and can be an important source of growth in the insurance industry but it was found to be insignificant. Although the results of the regression showed that value of quasi money to M2 ratio is statistically insignificant this variable my be a crucial factor in increasing demand for life insurance. This might due to the fact that a more developed financial institutions can increase competition with other financial sectors, especially insurance companies. This assertion is particularly appropriate for banking-type products offered by life insurers. The links between this two sectors, for instance, in Baltic 
countries were observed going back to the end of 1990th (several life insurance companies were the bank subsidiaries in Estonia, Lithuania and Latvia), the cooperation between the two sectors in CSEE countries is still in its initial stage. The mentioned cooperation is known as bancassurance - expressed in acquiring the existing life insurance companies by banks or, what is more common, selling of insurance and banking products mutually through bank branches. The upward trend for this kind of services is justified by the positive experience of Western economies. 35\% of sales in European life insurance market are accounted for bancassurance, which became a prevailing distribution channel for a number of Western economies including France, Spain, Italy and Belgium (Milliman, 2005).

The negative relationship between young dependency ratio and life insurance demand is not surprising. We expected ambiguous relationship. As young population earns no salary, they are not prompted to buy protection against early death in order to substitute actual salaries. Moreover, they cannot afford savings products. The old dependency ratio has also expected sign but it was found to be insignificant. It suggests that rising old dependency ratio will increase the demand for both the mortality and the savings component of life insurance policies. While the theoretical work focuses mostly on the life insurance policies held by primary wage earners, life insurance policies held by retirees have gained importance in many developed countries. This conclusion was confirmed in our study where we had as a sample of former socialist countries in Central and South- Eastern Europe.

The results in columns 1 indicate that out of our three indicators of institutional quality only the control of corruption is positively correlated with life insurance penetration, although is not significant. The coefficients on both the rule of law and government effectiveness are insignificant and have a negative sign. This can be interpreted as lack of evidence that these supply side deterninants are important.

\subsection{Life Insurance Density}

Now, proceeding to the density regression, the results indicate the following relationship: income level, average years of schooling, health expenditure to GDP and rule of law have a significant positive impact on the demand for life insurance, inflation influence significant negatively impact. These results are very similar to the ones obtained for life insurance penetration, so that in the following we will concentrate on the differences.

The important advantage of density regression is the significant impact of real personal income, which is highly supported by previous findings and shows that 1US dollars increase in income level of a person pushes life insurance density up by 11.56 US dollar.

The level of education also positively determines the demand for life insurance, indicating that the rise in average years of schooling by 1 year improves life life insurance density by 0.15 percentage points. This is relatively large impact of this socioeconomic factor comparing to other researchers, which emphasizes the importance of education in life insurance demand.

The coefficient of health expenditure is also positively determines the demand for life insurance.The hypothesis of a negative relationship, resulting from life insurance provided by social insurance programs substituting for private life insurance, is not supported by this study, postulates that $1 \%$ increase in health expenditure results in 1,70 percentage points increase in life insurance demand. These results show that there is a greater influence on life insurance density on than was the case with life insurance penetration.

The results from our three indicators of institutional quality only the rule of law is positively correlated and significant with life insurance density. The results do show evidence to support the hypothesis that quality of property right factors is determinants of life insurance consumption in economies. It indicates that uprise in ratio by $1 \%$ increase life insurance density by 2.210 percentage points.

Contrary to most previous studies the coefficient on the inflation rate is significantly negative in all specifications. So $1 \%$ increase in inflation rate would reduce life insurance density by 1.041 percentage points.

Such economic, demographic and institutional factors as real interest rates, quasimon/M2, young dependency ratio, old dependency ratio, control of corruption and government effectiveness do not explain variation in the demand for life insurance across the CSEE countries.

\section{Conclusion}

In this paper we have analyzed the determinants of life insurance demand in panel of 14 countries in Central and South- Eastern Europe over the period 1998 - 2010, using two indicators of life insurance demand, life insurance penetration and life insurance density.

Consistent with previous research, we find that life insurance penetration and life insurance density increase with higher per-capita income. The results indicate that, increase in per-capita income level have the robustly impact the 
life insurance demand. As overall income level and the share of middle class rises, we can expect demand for life insurance to rise too.

The analysis show that from economic variables QuasiMon/M2 have a positive but not significant effect on life insurance demand. But in our opinion as bancassurance will continue growing in the CSEE and, more important, in the CSEE countries and occupy its share in the life insurance products, the change in this relationship is expected. Although bancassurance is in its initial stage in CSEE countries, the tendency towards its growth is observed due to increase in consumers' crediting activity of the banks

The results also imply that real interest rates do not have robust link on life insurance density. Positive impact of real interest rate on the life insurance penetration in the selected countries may indicate the awareness of potential consumers about the benefits of life insurance and negligence to the mortality risk coverage. Inflation appears to have negative influence on life insurance demand, which is widely supported by previous researchers. Therefore, macroeconomic stability plays an important role in the development of life insurance market.

From the demographic factors we find that higher level of education lead to a higher life insurance penetration and higher life insurance density. This finding suggests a need for elevating the education level of population. It would be useful to enhance the understanding of financial products presented on the market and possible benefits from using them by potential consumers.

The results from the our regressions underline the importance of health expenditure with two indicators of life insurance demand. This result is consistent with the hypothesis that pension benefits represent assets which individuals protect against premature loss.

The results from institutional factors underline the importance of rule of law in life insurance density. Therefore, it is worth noticing that protection and enforcement of property rights will facilitate the demand of life insurance policies.

Whereas other factors, such real interest rates, young dependency ratio, old dependency ratio control of corruption and government effectiveness, do not have robust link to life insurance demand.

The results of this paper that the Central and South- Eastern Europe countries are regarded to be a highly potential region with dynamic and fact-growing insurance markets. Taking into account the impact of insurance development on economic growth (Ward and Zurbruegg, 2000, Webb, Grace and Skipper (2002) Arena (2008) the increase of life insurance sector should be viewed as inevitable part of stable economic development. In the future research when more data become available, would be useful to take a much bigger sample in terms of countries and periods would lead to a greater understanding and knowledge of determinants of life insurance demand.

\section{References}

Arena, M. (2008). Does Insurance Market Activity Promote Economic Growth? A Cross-Country Study for Industrialized and Developing Countries. Journal of Risk and Insurance, 75, 921-946. http://dx.doi.org/10.1111/j.1539-6975.2008.00291.x

Beck, T., \& Webb, I. (2002). Economic, Demographic, and Institutional Determinants of Life Insurance Consumption Across Countries. World Bank Economic Review, 17, 51-88. http://dx.doi.org/10.1093/wber/lhg011

Beck, T., \& Webb, I. (2003). Determinants of Life Insurance Consumption across Countries. World Bank and International Insurance Foundation.

Beenstock, M., Dickinson, G., \& Khajuria, S. (1986). The Determination of Life Premiums: An International Cross-Section Analysis 1970-1981. Insurance: Mathematics and Economics 5, 261-270. http://dx.doi.org/10.1016/0167-6687(86)90020-X

Beenstock, M., Dickinson, G., \& Khajuria, S.(1988). The Relationship between Property-Liability Insurance Premiums and Income: An International Analysis. Journal of Risk and Insurance, 55, 259-272. http://dx.doi.org/10.2307/253327

Burnett, J., \&Palmer, B. (1984). Examining Life Insurance Ownership Through Demographic and Psychographic Characteristics. Journal of Risk and Insurance,51,453-467. http://dx.doi.org/10.2307/252479

Browne, M.J., \& Kim, K. (1993). An International Analysis of Life Insurance Demand. Journal of Risk and Insurance, 60, 616-634. http://dx.doi.org/10.2307/253382

Campbell, R. A. (1980). The Demand for Life Insurance: An Application of the Economics of Uncertainty. Journal o f Finance 35, 1155-1172. http://dx.doi.org/10.2307/2327091

Fortune, P. (1973). A Theory of Optimal Life Insurance: Development and Tests. Journal of Finance, 28, 587-600. http://dx.doi.org/10.2307/2978631 
Hemming, R., \& Manson, A.(1988). Is Privatization the Answer? Finance and Development, 25(3), 31-33.

Im, K.S., Pesaran, M.H., \& Shin, Y. (2003). Testing for Unit Roots in heterogeneous Panels. Journal of Economics. 115, 53-74.

Lewis, F. D. (1989). Dependents and the Demand for Life Insurance. American Economic Review 79, 452-466.

Lenten,J.A., \& Rulli, D.N. (2006). A Time-Series Analysis of the Demand for Life Insurance Companies in Australia: An Unobserved Components Approach. Australian Journal of Management, 31, 41-66. http://dx.doi.org/10.1177/031289620603100104

Levine, R. (1997). Financial Development and Economic Growth: Views and Agenda. Journal of Economic Literature 35, 688-726.

Levine, R. (1998). The Legal Environment, Banks, and Long-run Economic Growth. Journal of Money, Credit, an dBanking 30,596-620. http://dx.doi.org/10.2307/2601259

Li., Donghui, Moshirian, F., Nguyen, P., \& Wee, T. (2007). The Demand for Life Insurance in OECD. The Journal of Risk and Insurance 74, 637 - 652.

Liu, L. Y., \& Woo, W. T. (1994). Saving Behaviour under Imperfect Financial Markets and the Current Account Consequences. Economic Journal, 104, 512-527. http://dx.doi.org/10.2307/2234628

Lorent, B. (2010). The Link between Insurance and Banking Sectors: An International Cross-Section Analysis of Life Insurance Demand. Working Papers CEB.

Outreville, J. F. (1996).Life Insurance Markets in Developing Countries. Journal of Risk and Insurance 63.

Skipper, H. D., \& Klein, R. W. (2000). Insurance Regulation in the Public Interest: The Path Towards Solvent, Competitive Markets. The Geneva Papers on Risk and Insurance, 25, 482-504. http://dx.doi.org/10.1111/1468-0440.00078

Truett, D.B., \& Truett L.J. (1990). The Demand for Life Insurance in Mexico and the United States: A Comparative Study. The Journal of Risk and Insurance 57, 321-328. http://dx.doi.org/10.2307/253306

Ward, D., \& Zurbruegg, R. (2002). Law, Politics and Life Insurance Consumption in Asia. Geneva Papers on Risk and Insurance, 27, 395-412. http://dx.doi.org/10.1111/1468-0440.00181

Ward, D., \& Zurbruegg, R. (2000). Does Insurance Promote Economic Growth? Evidence from OECD Countries. The Journal of Risk and Insurance, 67 (4), 489-506. http://dx.doi.org/10.2307/253847

Webb, I., Grace, M.F., \& Skipper, H. (2002). The effect of banking and insurance on the growth of capital and output. Georgia State University Working paper.

White, H. (1980). A Heteroskedasticity-Consistent Covariance Matrix Estimator and a Direct Test for Heteroskedasticity. Econometrica,48,817-838. http://dx.doi.org/10.2307/1912934

Yaari, M.E. (1965). Uncertain Lifetime, Life Insurance, and the Theory of the Consumer. Review of Economic Studies, 32, 137-150. http://dx.doi.org/10.2307/2296058

Table 1. Descriptive Statistics

\begin{tabular}{|c|c|c|c|c|c|}
\hline Variable & Mean & Median & Minimum & Maximum & Std. Dev. \\
\hline & & & & & \\
Life insurance penetration & 0,697447 & 0,500000 & 0,000500000 & 3,10000 & 0,616695 \\
Life insurance density & 72,0184 & 25,3000 & 0,00800000 & 465,700 & 100,462 \\
GDP per capita & 7,44053 & 5,60500 & 0,313000 & 26,9110 & 5,50366 \\
Real interest rates & 5,96494 & 5,70000 & $-12,6000$ & 37,9000 & 6,28183 \\
QuasiMon/M2 & 16,7389 & 14,1500 & $-99,4000$ & 145,200 & 19,2771 \\
Inflation & 6,83846 & 4,40000 & $-2,30000$ & 55,2000 & 8,25363 \\
Young dependency ratio & 17,1703 & 16,0000 & 13,0000 & 31,0000 & 3,48614 \\
Old dependency ratio & 14,1703 & 15,0000 & 7,00000 & 18,0000 & 2,53780 \\
Education level & 50,3536 & 50,0000 & 15,0000 & 88,0000 & 18,2792 \\
Health expenditure to GDP & 6,79613 & 6,80000 & 4,60000 & 10,1000 & 1,02569 \\
Rule of Law & 0,230672 & 0,398227 & $-1,24346$ & 1,22419 & 0,632538 \\
Control of Corruption & 0,0760387 & 0,171488 & $-1,15830$ & 1,29689 & 0,541978 \\
Government Effectiveness & 0,352113 & 0,532759 & $-0,952360$ & 1,22157 & 0,583592 \\
& & & & & \\
\hline
\end{tabular}


Table 2. Panel Unit Root Test - Im, Pesaran and Shin (IPS)

\begin{tabular}{|l|c|c|}
\hline \multicolumn{1}{|c|}{ Variable } & Im, Pesaran and Shin Test & Order of Integration \\
\hline Life insurance penetration & $-1,25236$ & $\mathrm{I}(1)$ \\
Life insurance density & $-0,546255$ & $\mathrm{I}(1)$ \\
GDP per capita & $-0,557758$ & $\mathrm{I}(1)$ \\
Real interest rates & $-3,21412^{* * *}$ & $\mathrm{I}(0)$ \\
QuasiMon/M2 & $-2,68304 * * *$ & $\mathrm{I}(0)$ \\
Inflation & $-3,50959^{* * *}$ & $\mathrm{I}(0)$ \\
Young dependency ratio & $-1,64284$ & $\mathrm{I}(1)$ \\
Old dependency ratio & $-1,09956$ & $\mathrm{I}(1)$ \\
Education level & $-2,19729^{* * *}$ & $\mathrm{I}(0)$ \\
Health expenditure to GDP & $-1,73602^{* * *}$ & $\mathrm{I}(0)$ \\
Rule of Law & $-3,90002^{* * *}$ & $\mathrm{I}(0)$ \\
Control of Corruption & $-4,2451^{* * *}$ & $\mathrm{I}(0)$ \\
Government Effectiveness & $-3,68991^{* * *}$ & $\mathrm{I}(0)$ \\
\hline
\end{tabular}

*,**and***indicates test statistic is significant at the $10 \%, 5 \%$ and $1 \%$ level.

Table 3. Estimation results

\begin{tabular}{|c|c|c|}
\hline Variable & Dependent variable: Life insurance penetration & Dependent variable: Life insurance density \\
\hline Const & $\begin{array}{r}0,0227057 \\
(0,0152934)\end{array}$ & $\begin{array}{l}0,41238 \\
(2,0081)\end{array}$ \\
\hline GDP per capita & $\begin{array}{r}0,0168362 * * * \\
(0,00949187)\end{array}$ & $\begin{array}{c}11,5568 * * * \\
(1,29823)\end{array}$ \\
\hline Real interest rates & $\begin{array}{l}-0,00241964 \\
(0,00283315)\end{array}$ & $\begin{array}{l}-0,383954 \\
(0,351046)\end{array}$ \\
\hline QuasiMon/M2 & $\begin{array}{c}6,35491 \mathrm{e}-05 \\
(0,000466415)\end{array}$ & $\begin{array}{c}0,0484918 \\
(0,0472744)\end{array}$ \\
\hline Inflation & $\begin{array}{l}-0,00162014 \\
(0,00318447)\end{array}$ & $\begin{array}{l}-1,04102 * \\
(0,545763)\end{array}$ \\
\hline Young dependency ratio & $\begin{array}{l}-0,0016596 \\
(0,0243775)\end{array}$ & $\begin{array}{l}-0,577787 \\
(3,04295)\end{array}$ \\
\hline Old dependency ratio & $\begin{array}{l}0,00712641 \\
(0,0313043)\end{array}$ & $\begin{array}{l}-1,11683 \\
(3,93174)\end{array}$ \\
\hline Education level & $\begin{array}{c}0,0044079 * \\
(0,00164312)\end{array}$ & $\begin{array}{l}0,149345^{*} \\
(0,245234)\end{array}$ \\
\hline Health expenditure to GDP & $\begin{array}{c}0,011221^{*} \\
(0,0123009)\end{array}$ & $\begin{array}{l}1,69694 * \\
(1,91384)\end{array}$ \\
\hline Rule of Law & $-0,000368588$ & $2,21082 *$ \\
\hline Control of Corruption & $\begin{array}{c}(0,0689616) \\
0,0840193\end{array}$ & $\begin{array}{l}(7,5165) \\
12,0439\end{array}$ \\
\hline Government Effectiveness & $(0,0592414)$ & $(6,82207)$ \\
\hline Mean dependent var & $-0,0554055$ & $-10,2779$ \\
\hline Sum squared resid & $(0,0750332)$ & $(6,95669)$ \\
\hline R-squared & 0,046110 & 8,760179 \\
\hline $\mathrm{F}(18,111)$ & 4,435753 & 70874,12 \\
\hline Log-likelihood & 0,082222 & 0,424133 \\
\hline Schwarz criterion & 0,533799 & 4,388378 \\
\hline S.D. dependent var & $-66,89672$ & $-746,1362$ \\
\hline S.E. of regression & 5,694335 & 1620,371 \\
\hline Adjusted R-squared & 0,170121 & 27,14716 \\
\hline P-value $(F)$ & 0,176123 & 22,26260 \\
\hline Akaike criterion & 0,071810 & 0,327484 \\
\hline Hannan-Quinn & 0,042829 & 0,007908 \\
\hline Durbin-Watson & 83,79343 & 1542,272 \\
\hline & 52,09702 & 1573,969 \\
\hline & 2,224837 & 2,385445 \\
\hline
\end{tabular}

Standard errors in parentheses. $* * *, * *, *$ denote statistical significance at the $1,5,10$ percent level $=$ 